\title{
Investigation into the Biogas Production Potential of Dairy Cattle Manure
}

\author{
Christy E. Manyi-Loh, Sampson N. Mamphweli, Edson L. Meyer, Anthony I. Okoh, Golden Makaka, \\ and Michael Simon, Member, CBEES
}

\begin{abstract}
We investigated the biogas production potential of dairy cattle manure obtained from the Fort Hare Dairy Farm, Eastern Cape Province of South Africa. A balloon type digester was charged with slurry of manure and operated under anaerobic digestion mode for six months. Fifty milliliters of slurry was withdrawn at different time intervals to analyze the microbial counts and physicochemical parameters by viable plate count method and standard methods, respectively. Data demonstrated that the $\mathrm{pH}$ and temperature ranged from 5.68-7.63 and $17.0-25.04{ }^{\circ} \mathrm{C}$, respectively. The total aerobic and anaerobic bacteria counts ranged from1.0 $\times 10^{4}-7.5 \times 10^{6}$ and 4 $\times 10^{2}-1.8 \times 10^{6} \mathrm{cfu} / \mathrm{g}$, respectively, as well as the total yeast counts ranged from $2 \times 10^{2}-1.0 \times 10^{6} \mathrm{cfu} / \mathrm{g}$. A linear regression model was developed that predicted the relationship between log total bacteria count and average slurry temperature, $\mathrm{pH}$ and days of digestion. The $11.2 \% \mathrm{TS}, \mathbf{6 1 . 5 \%} \mathrm{VS}$ and $32.5 \%$ ash content of the manure indicated that the dairy manure constituted of biodegradable portion. Biogas $\left(4600 \mathrm{~cm}^{3}\right)$ was produced during digestion and was combustible after 120 days. Thus, we concluded that dairy manure harbors a considerable level of anaerobic bacteria and methanogens that participated effectively to degrade the organic portion of manure generating renewable energy.
\end{abstract}

Index Terms-Anaerobic digestion, balloon digester, biogas, dairy manure, microbial count.

\section{INTRODUCTION}

Livestock practices generate copious quantities of animal manure that warrants proper management. Consequently, there is a need for prompt intervention for proper disposal and management of these wastes in a bid to evade the adverse environmental and public health consequences (e.g. pathogen contamination, odor, air borne ammonia, green house gases etc) [1]. Interestingly, anaerobic digestion of animal manure in biogas digester has shown promise as a technology that will generate biogas, a renewable energy source that could be used for heating and other purposes and in addition aids in the proper management of these wastes by reducing the microbial load [2].

Furthermore, digestion of dairy manure through the anaerobic process entails the breakdown of organic matter contained therein by the concerted interplay of four sets of metabolically linked microbes via the hydrolytic, acidogenic, acetogenic and methanogenic stages to yield methane, carbon dioxide and other trace gases [3]. Overall, organic waste materials constitute of sufficient quantities of nutrients vital for the growth and metabolism of the anaerobic bacteria involved in biogas production [4]. Apart, from these bacteria, protozoa and fungi are the other groups of microorganisms that are present in animal manure [5].

Traditionally, at the Fort Hare Dairy Farm, the animal manure is being flushed with water into a lagoon located some distances from the farm for storage and treatment. However, this creates a nuisance to the environment due to the fact that the lagoon is uncovered and the stored manure generates and releases methane and carbon dioxide into the atmosphere [6]. These green house gases contribute in global warming [7]. In addition, the air around and close to the vicinity is polluted with malodorous compounds resulting from the incomplete breakdown of the organic fraction in the manure by the indigenous rumen microorganisms under uncontrolled environment. Therefore, the installation and implementation of a biodigester on the farm and utilization of the dairy waste as a feedstock to recover biogas will be a cheaper source of energy as well as a good waste management option.

Regardless of the fact that animal manure has been employed in biogas production through mono or co-digestion studies elsewhere [8]-[11], however, the biogas potential varies with the chemical composition, microbial and biological availability of the nutrients present in animal wastes. Concisely, the weather and soil characteristics might influence the physicochemical characteristics of these wastes as well as the species of animal, dietary sources, health status of the animals and factors affecting growth and age of the animals [5], [12].

In this paper, we investigated the biogas production potential of dairy manure obtained from the Fort Hare Dairy Farm, Eastern Cape Province of South Africa by monitoring the physicochemical parameters and microbial level of the digesting substrate throughout the anaerobic digestion process in a balloon type digester operating in a batch mode under mesophilic temperature condition. In addition, a model was developed to elucidate the relationship between the bacterial activity, $\mathrm{pH}$ and temperature and also to predict biogas yield in future studies.

\section{MATERIALS AND METHODS}

as supported in part by the Claude Leon Foundation, South Africa and Fort Hare Institute of Technology, South Africa.

The authors are with the University of Fort Hare, Alice, 5700, South Africa (e-mail: cmanyi-loh@ufh.ac.za, smamphweli@ufh.ac.za, emeyer@ufh.ac.za, aokoh@ufh.ac.za, gmakaka@ufh.ac.za, msimon@ufh.ac.za).

\section{A. Raw Anaerobic Digestion Material (Dairy Cattle Manure)}

A total of $1700 \mathrm{~L}$ of fresh dairy cow manure was obtained 
from the Fort Hare Dairy Farm, Alice on three consecutive days and were referred to as samples A, B and C. The characteristics of the wastes are presented in Table 1.The study was conducted from October 2013 to April 2014, at the Fort Hare Institute of Technology Research Centre, Alice campus.

TABLE 1: CHARACTERISTICS OF SAMPLES A, B AND C EMPLOYED IN FEEDING

\begin{tabular}{lllll}
\hline Parameters & Sample A & Sample B & Sample C & Mean \\
\hline $\begin{array}{l}\text { \%moisture } \\
\text { content }\end{array}$ & 86.6 & 89.3 & 90.4 & 88.8 \\
\%Total solids & 13.4 & 10.7 & 9.6 & 11.2 \\
\%Volatile solids & 72 & 47.8 & 64.6 & 61.5 \\
\%ash content & 29.8 & 32.3 & 35.4 & 32.5 \\
$\begin{array}{l}\text { Ammonium level } \\
\text { (mg/ml) }\end{array}$ & 2.1 & 2.3 & 2.2 & 2.2 \\
pH & 6.3 & 6.95 & 6.46 & 6.57 \\
\hline
\end{tabular}

\section{B. Experimental Set up and Sampling}

A balloon digester was housed within a concrete structure $\left(8 \mathrm{~m}^{3}\right)$ constructed originally into three compartments: feeding tank of height $83 \mathrm{~cm}$, width $89 \mathrm{~cm}$ and length $95 \mathrm{~cm}$; bioreactor tank of height $3.25 \mathrm{~m}$ and width $2 \mathrm{~m}$ and lastly, the effluent tank (Fig. 1). The balloon digester was charged on three consecutive days with a homogenous mixture of dairy cow manure and water in the ratio $1: 1$. The mixing ratio of waste to water for the preparation of the slurry was determined by the moisture content of the waste [13]. The physicochemical parameters $(\mathrm{pH}$, moisture, \% TS, \%VS, ammonium level and $\%$ ash content) of undigested wastes were determined before the slurry was prepared. The digester operated under batch mode over a six month period. Samples were withdrawn every three, seven and fourteen day interval for the analysis of microbial load while the $\mathrm{pH}$ and temperature were monitored daily throughout the study.

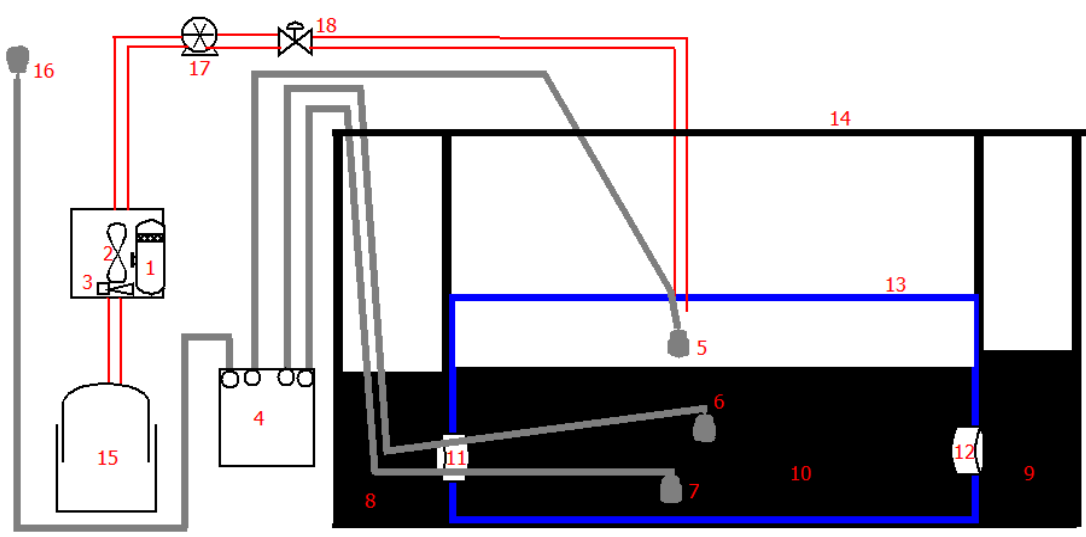

1, Campbell data logger; 2, Gas analyzer; 3, flow transducer; 4, hobo data logger; 5,produce gas temperature sensor; 6 ,intermediate slurry temperature sensor; 7 , bottom slurry temperature sensor; 8 , inlet chamber; 9 , outlet chamber; 10 , slurry trap inside balloon; 11 , slurry inlet; 12 , slurry outlet; 13 , balloon digester; 14, insulation cover; 15, gas collection chamber; 16, ambient temperature sensor; 17 , pump; 18 , open and close valve

Fig. 1. Layout of the designed and constructed and balloon digester with the data acquisition system incorporated into the full schematic diagram.

\section{Physicochemical Analysis of Slurry Samples}

\section{1) Determination of ammonium level of sample}

Ammonium level was determined according to the method described by Ziganshin et al. [14]. Slurry samples were each centrifuged at 20,000xg for 20mins and the supernatant was decanted and colored with Nessler's reagent. The absorbance of the colored solutions was measured at $425 \mathrm{~nm}$ wavelength by Hexios, Thermo Spectronics (Merck, Darmstadt, Germany) spectrophotometer and calculations were done considering that the standard (ammonia solution) had a concentration of $0.909 \mathrm{~g} / \mathrm{mL}$. Also, distilled water was used as a blank to nullify the absorbance of water in both the samples and standard.

\section{2) Determination of moisture content of samples}

As per the method of Cioabla et al. [15], samples were weighed in a dish and dried in an oven at $105^{\circ} \mathrm{C}$ overnight. The weight of the dried sample plus dish was noted and the percentage moisture content was calculated by this equation;

$$
\% \text { moisture content }=\left(m_{2}-m_{1}\right)-\left(m_{3}-m_{1}\right) /\left(m_{2}-m_{1}\right) ; 100
$$

where $m_{1}=$ mass in grams of the empty dish, $m_{2}=$ mass in grams of sample plus the empty dish before drying, $m_{3}=$ mass in grams of sample plus empty dish after drying.

\section{3) Determination of dry matter (total solids)}

Percentage of total solids was determined according to the method of Asam et al. [16]. A known weight of sample $\left(\mathrm{W}_{\mathrm{S}}\right)$ in a dish was dried at $105^{\circ} \mathrm{C}$ in an oven for $24 \mathrm{~h}$. After drying, the weight of sample was measured and recorded as $\mathrm{W}_{\mathrm{DM}}$. Percentage of total solids was calculated as follows:

$$
\% \text { total solids }=100 \times W_{D M} / W_{S}
$$

\section{4) Determination of volatile solid Content and ash content}

Following the determination of total solids, the overnight dried sample was combusted in a muffle furnace at $550^{\circ} \mathrm{C}$ for 1h. The weight of the ash plus the dish was taken and percentage of volatile solid was then calculated from the formula:

$$
\% \text { volatile solid }=100 \times\left(W_{D M}-W_{a s h}\right) / W_{D M}
$$

Furthermore, the percentage of ash content was determined from the expression proposed by Cioabla et al. [15] as follows:

$\%$ ash content $=\left(m_{3}-m_{1}\right) / m_{2}-m_{1} ; 100 ; 100 / 100-\%$ moisture $(4)$ 
where $m_{3}=$ mass in grams of ash plus empty dish, $m_{2}$ and $m_{1}$ are as referred above.

\section{5) Determination of $\mathrm{pH}$, temperature and biogas production}

Daily ambient and slurry temperature were measured by four temperature sensors connected externally to a data logger (U12, Hobo), configured to log every 30 minute interval. The $\mathrm{pH}$ was measured by a PHSCAN 30, $\mathrm{pH}$ meter. The cumulative volume of biogas generated was recorded by a gas analyzer. Triplicate determinations were carried out on each parameter.

\section{Microbial Analysis of Samples}

\section{1) Bacterial counts}

Total viable count was conducted on undigested and withdrawn samples during digestion according to the method described by Poudel et al. [17]. Each sample was aseptically collected, introduced into tryptic soy broth medium in sterile centrifuge tubes and transported on ice to the laboratory [18]. Samples were analyzed immediately upon arrival at the "Applied and Environmental Microbiology Research Group" laboratory. Evaluation of the total viable counts was conducted as follows: $1 \mathrm{~g}$ of each sample was serially diluted tenfold in $9 \mathrm{~mL}$ of sterile physiological saline. Dilutions from $10^{-1}$ to $10^{-5}$ were spread in triplicates on different microbiological media, including Nutrient agar (Merck, South Africa), Anaerobic agar (Conda, Spain), and Potato Dextrose agar (Conda, Spain) to obtain total aerobic bacteria counts, total anaerobic bacteria counts, and total yeast counts, respectively.

All inoculated plates were incubated at $37^{\circ} \mathrm{C}$ for $24 \mathrm{hrs}$, except that the plates for total yeast counts were incubated at $28^{\circ} \mathrm{C}$ for 4 days. After incubation, the number of emergent colonies on each plate was counted, recorded and each value represented the mean of triplicate plating [19].

\section{E. Development and Building of a Mathematical Model}

A linear regression model was developed to predict the relationship between slurry temperature, $\mathrm{pH}$, days of digestion and log bacterial count (total number of aerobic and anaerobic bacteria count).

\section{F. Statistical Analysis}

The experimental data were processed and analyzed using Matlab software (R2013a).

\section{RESULTS AND DISCUSSION}

Data on \% total solids, total volatile solids, and ash content indicated that the cow manure constituted of biodegradable portion that could be digested for the release of biogas by the microorganisms contained therein [20].

At the point of charging, the total aerobic bacteria, anaerobic bacteria and yeast counts were high as shown in Table II. This affirms the fact that cow manure is a suitable substrate of biogas production since rumen microorganisms demonstrate significant roles in anaerobic digestion to degrade the organic portion of dairy cattle manure [1]. From the public health perspective, the total microbial load as depicted from the Table II, below revealed that dairy cow manure is a highly potential source of both water and soil pollution when the manure is not being treated effectively before it is released into the environment through soil application in agriculture for better crop yield. This poses threats to animals and humans as infection is possible since modes of transmission become feasible [21].

Furthermore, the performance of an anaerobic digester is strongly influenced by the $\mathrm{pH}$ and temperature of digesting substrate [15]. Livestock wastes including dairy manure have been reported to have high buffering capacity producing alkalinity when degraded upon by the microorganisms [22]. Consequently, in this study the $\mathrm{pH}$ of the digesting medium was unregulated. However, in the first two months of digestion (Fig. 2), a decrease in $\mathrm{pH}$ of the medium (from 6.57 at the point of charging to 5.82) was observed which could be attributed to the high concentration of volatile fatty acids, bicarbonate alkalinity and carbon dioxide; end products of the early stages of anaerobic digestion process (hydrolysis \& acidogenesis [3]. This result corroborates the findings of $\mathrm{Li}$ et al. [23] and Abubakar and Ismail [1]. As the process progresses, the volatile fatty acids were metabolized and the $\mathrm{pH}$ gradually increased to the sufficient buffering capacity (neutral $\mathrm{pH}$ ) necessary for the production of biogas [23]. Moreover, both acidogenic and methanogenic microorganisms have their optimal $\mathrm{pH}$ for metabolism [11], but the methanogens are highly $\mathrm{pH}$ sensitive and thrive optimally within the $\mathrm{pH}$ range of 6.6-7.6 [24]. This explains the high flammability rate of the biogas in this study, at $\mathrm{pH}$ 7.45 on the $121^{\text {st }}$ day of the digestion process owing to the increase in methanogenic activity of the digester system.

TABLE II: TOTAL MiCROBIAL COUNTS BEFORE AND DURING THE ANAEROBIC DIGESTION PROCESS

\begin{tabular}{|c|c|c|c|}
\hline $\begin{array}{c}\text { Days of } \\
\text { digestion }\end{array}$ & TAC & TANC & TYC \\
\hline 0 & $2.7 \times 10^{6}$ & $2.3 \times 10^{6}$ & $7.9 \times 10^{5}$ \\
\hline 3 & $3.6 \times 10^{6}$ & $2.0 \times 10^{6}$ & $2.6 \times 10^{5}$ \\
\hline 6 & $7.0 \times 10^{5}$ & $3.0 \times 10^{5}$ & $2.0 \times 10^{5}$ \\
\hline 9 & $5.0 \times 105$ & $3.0 \times 10^{5}$ & $1.1 \times 10^{5}$ \\
\hline 14 & $4.4 \times 10^{4}$ & $6.9 \times 10^{3}$ & $1.7 \times 10^{4}$ \\
\hline 19 & $1.8 \times 10^{4}$ & $2.0 \times 10^{3}$ & $2.5 \times 10^{4}$ \\
\hline 24 & $5.5 \times 10^{4}$ & $1.0 \times 10^{3}$ & $9.3 \times 103$ \\
\hline 29 & $9.0 \times 10^{4}$ & $2.6 \times 10^{3}$ & $2.0 \times 10^{4}$ \\
\hline 34 & $4.0 \times 10^{4}$ & $3.3 \times 10^{3}$ & $1.6 \times 10^{4}$ \\
\hline 41 & $8.5 \times 10^{4}$ & $7.0 \times 10^{2}$ & $2.2 \times 10^{4}$ \\
\hline 48 & $2.1 \times 10^{5}$ & $4.0 \times 10^{2}$ & $2.0 \times 10^{4}$ \\
\hline 55 & $4.8 \times 10^{5}$ & $4.1 \times 10^{3}$ & $3.0 \times 10^{3}$ \\
\hline 62 & $4.5 \times 10^{5}$ & $1.1 \times 10^{4}$ & $2.5 \times 10^{3}$ \\
\hline 76 & $3.0 \times 10^{4}$ & $1.0 \times 10^{4}$ & $8.0 \times 10^{2}$ \\
\hline 83 & $6.6 \times 10^{5}$ & $8.0 \times 10^{3}$ & $3.3 \times 10^{3}$ \\
\hline 121 & $5.0 \times 10^{4}$ & $5.0 \times 10^{3}$ & $5.0 \times 10^{2}$ \\
\hline 133 & $2.6 \times 10^{4}$ & $1.3 \times 10^{3}$ & $2.1 \times 10^{3}$ \\
\hline 143 & $4.5 \times 10^{4}$ & $2.8 \times 10^{3}$ & $1.3 \times 10^{4}$ \\
\hline 150 & $2.3 \times 10^{4}$ & $1.6 \times 10^{3}$ & $1.5 \times 10^{4}$ \\
\hline 161 & $1.5 \times 10^{4}$ & $4.5 \times 10^{4}$ & $2.5 \times 10^{3}$ \\
\hline 171 & $2.3 \times 10^{3}$ & $3.5 \times 10^{5}$ & $2.3 \times 10^{3}$ \\
\hline 178 & $2.3 \times 10^{3}$ & $9.8 \times 10^{3}$ & $2.4 \times 10^{3}$ \\
\hline
\end{tabular}

TAC- Total aerobic bacterial counts; TANC-Total anaerobic bacterial count; TYC-Total yeast count.

In addition, the metabolic rate of microorganisms has been reported to be influenced by temperature thus it modifies the effectiveness of these anaerobic microbes relevant in the process of biogas production. Accordingly, the temperature 
profile was monitored by four temperature sensors; two sensors were embedded at different levels in the slurry, one was floating in the biogas space and the last was located outside the digester (within the concrete housing detecting ambient temperature) but all were connected to a Hobo data logger for data recording and storage.

The variation of daily average temperature (slurry) over the duration of anaerobic digestion is presented on Fig. 3 and is unaffected by the ambient temperature. Generally, it was noted that there was combined regimes of psychrophilic process $\left(<20^{\circ} \mathrm{C}\right)$ for the first two months and mesophilic process $\left(>20^{\circ} \mathrm{C}<30^{\circ} \mathrm{C}\right)$ for the rest of the process (4months) [25]. This result is in accordance with the findings of Cioabla et al. [15], although they evaluated the factors affecting anaerobic digestion of agricultural vegetal residues.

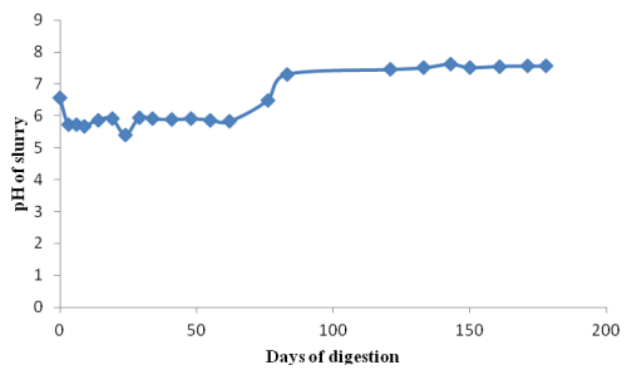

Fig. 2. Variation of $\mathrm{pH}$ of substrate during the anaerobic digestion process.

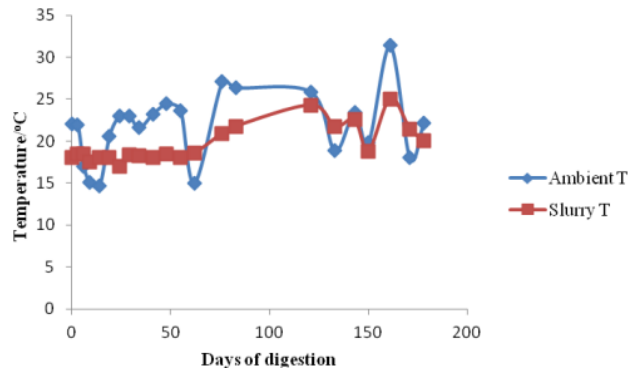

Fig. 3. Variation of temperature (slurry \& ambient) during anaerobic digestion.

TABLE III: INPUT PARAMETERS AND THE OUTPUT THAT WERE UTILIZED IN DEVELOPING THE MULTIPLE LiNEAR REGRESSION MODEL

\begin{tabular}{|c|c|c|c|}
\hline $\begin{array}{ll}\begin{array}{l}\text { No. } \\
\text { days }\end{array} & \text { of } \\
\end{array}$ & $\begin{array}{l}\text { Average slurry } \\
\text { temperature }\left({ }^{\circ} \mathrm{C}\right)\end{array}$ & $\mathrm{pH}$ value & $\begin{array}{l}\text { Log of total } \\
\text { Bacteria counts }\end{array}$ \\
\hline 0 & 18 & 6.57 & 6.12 \\
\hline 3 & 18.49 & 5.72 & 5.80 \\
\hline 6 & 18.46 & 5.73 & 5.85 \\
\hline 9 & 17.53 & 5.68 & 5.70 \\
\hline 4 & 18.02 & 5.87 & 4.64 \\
\hline 19 & 8.02 & 5.91 & 4.26 \\
\hline 24 & 17 & 5.4 & 4.74 \\
\hline 29 & 18.38 & 5.94 & 5.34 \\
\hline 34 & 18.24 & 5.9 & 5.24 \\
\hline 41 & 18.02 & 5.88 & 5.11 \\
\hline 48 & 18.49 & 5.9 & 5.09 \\
\hline 55 & 18.02 & 5.87 & 4.90 \\
\hline 62 & 18.54 & 5.82 & 4.80 \\
\hline 76 & 20.92 & 6.48 & 5.037 \\
\hline 83 & 21.77 & 7.3 & 5.39 \\
\hline 121 & 24.27 & 7.45 & 4.99 \\
\hline 133 & 21.7 & 7.5 & 4.42 \\
\hline 143 & 22.55 & 7.62 & 4.40 \\
\hline 150 & 18.83 & 7.51 & 3.90 \\
\hline 161 & 25.04 & 7.55 & 4.18 \\
\hline 171 & 21.43 & 7.56 & 3.78 \\
\hline 178 & 20.09 & 7.56 & 3.39 \\
\hline
\end{tabular}

A linear regression model was developed to predict the relationship between average slurry temperature, $\mathrm{pH}$, and days of digestion and $\log$ bacterial counts. These are all the parameters that have been reported to influence the production of biogas [15]. From Table III, the predictors were number of days $(n)$, average slurry temperature $(T)$, and the $\mathrm{pH}$ while the response was the logarithm of the total bacterial counts $(Y)$. The multiple linear regression model is as shown in the equation below:

$$
Y=A 0+A 1(n)+A 2(T)+A 3(\mathrm{pH})
$$

where $A 0=$ Forcing constant; $A 1=$ Scaling constant of $n ; A 2=$ Scaling constant of $T, A 3=$ Scaling constant of $\mathrm{pH}$.

\begin{tabular}{cccc} 
TABLE IV: SCALING VALUES OF THE RESPECTIVE SCALING CONSTANT \\
\hline Predictor symbol & $\begin{array}{c}\text { Scaling } \\
\text { symbol }\end{array}$ & Scaling Value & $\begin{array}{c}\text { Output } \\
\text { symbol }\end{array}$ \\
\hline constant & $A 0$ & 1.671 & $Y$ \\
$n$ & $A 1$ & -0.018 & \\
$T$ & $A 2$ & 0.106 & \\
$\mathrm{pH}$ & $A 3$ & 0.383 & \\
\hline
\end{tabular}

In addition, the measured log of total bacterial counts and the model of log of the total bacterial counts derived from the data set of Table I are as shown in Fig. 3. The measured and the modeled output were strongly correlated with a determination coefficient $\left(r^{2}\right)$ and a P-value of 0.94 and 0.85 , respectively. The large $r^{2}$ value showed that the measured $Y$ fit the modeled equation and also the P-value depicted that the modeled equation has a statistical significance of over $80 \%$ in agreement to the calculated response. The modeled equation coefficients predicted that an increase in average slurry temperature and $\mathrm{pH}$ could likely result to an increase in the logarithm of total bacterial counts.

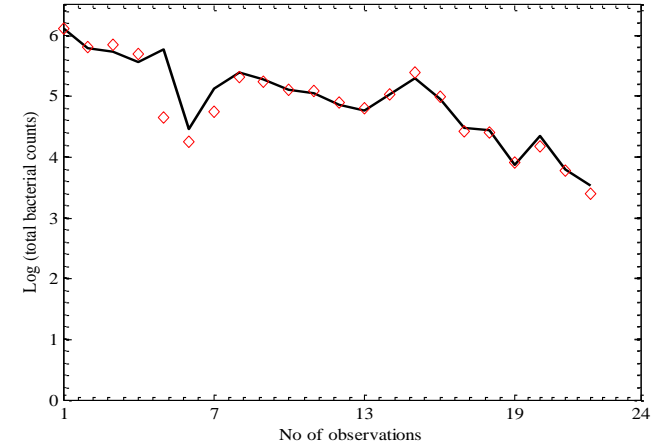

Fig. 3. Shows calculated and modeled log bacterial counts.

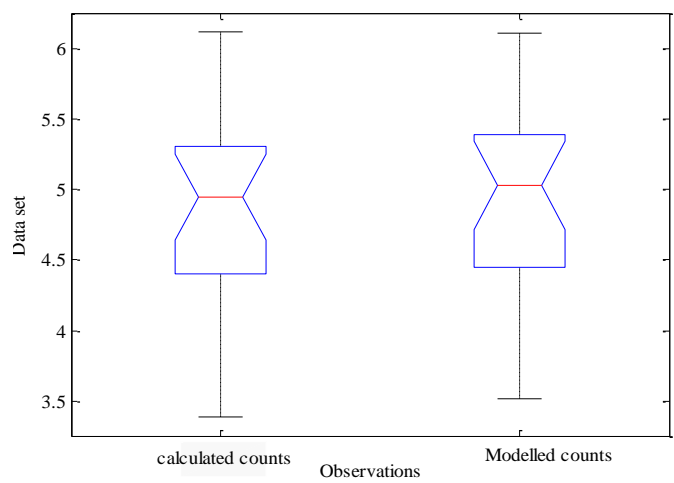

Fig. 4. ANOVA plot of calculated and modeled bacterial counts. 
It is evident that temperature increases microbial metabolism thereby converting volatile fatty acids into the desired end products [6]. Consequently, the concerted interplay of these microbes culminated in the production of biogas whose cumulative value was $4600 \mathrm{~cm}^{3}$ at the end of the study. However, an increase in the number of days can often bring about a drop in the output. This may probably be owing to exhaustion of nutrients since anaerobic bacteria needs suitable nutrients to thrive in any environment that they are kept.

Furthermore, the one way ANOVA test was performed between the measured and modeled log of total bacterial counts as illustrated in Fig. 4. The test showed no mean significant difference. Moreover, the data set of both the measured and modeled output showed a normal distribution with no outlier. The mean of both dataset from the ANOVA plot was 4.945 and 5.030, respectively.

\section{CONCLUSION}

From the results of this study, it is worth mentioning that dairy cattle manure is endowed with a considerable biogas production potential evaluated through anaerobic decomposition that offers numerous benefits of environmental, agricultural and socio-economic standards.

\section{ACKNOWLEGMENT}

Special thanks to Mr. S. L. Tangwe, Mr. May, Makhozanele and Mr. Ndlovu Filipu for technical assistance.

\section{REFERENCES}

[1] B. S. U. I. Abubakar and N. Ismail, "Anaerobic digestion of cow dung for biogas production," ARPN J. Eng. Appl. Sci., vol. 7, no. 2, pp. 169-172, February, 2012.

[2] C. E. Manyi-Loh, S. N. Mamphweli, E. L. Meyer, A. I. Okoh, G. Makaka, and M. Simon, "Microbial anaerobic digestion as an approach to the decontamination of animal wastes in pollution control and generation of renewable energy," Int. J. Environ. Res. Public Health, vol. 10, pp. 4390-4417, September, 2013.

[3] C. J. S. Lozano, M. V. Mendoza, M. C. de Arango, and E. F. C. Monroy, "Microbiological characterization and specific methanogenic activity of anaerobe sludges used in urban solid waste treatment," Waste Manage, vol. 29, pp. 704-711, February, 2009.

[4] W. Anunputtikul and S. Rodtong, "Laboratory scale experiments for biogas production from cassava tubers," in Proc. the Joint International Conference on Sustainable Energy and Environment, Hua Hin, Thailand, 2004, pp. 238-243.

[5] M. Spiehs and S. Goyal, "Best management practices for pathogen control in manure management systems," University of Minnesota Extension, M1211, 2007.

[6] B. St-Pierre and A. D. G Wright, "Metagenomic analysis of methanogen populations in three full- scale mesophilic anaerobic manure digesters operated on dairy farms in Vermont, USA," Bioresour. Technol., vol. 138, pp. 277-284, April 2013.

[7] V. Ramanathan and Y. Feng, "Air pollution, greenhouse gases and climate change: Global and regional perspectives," Atmos. Environ., vol. 43, pp. 37-50, January, 2009.

[8] S. Grant and A. Marshalleck, "Energy production and Pollution mitigation from broilers houses on poultry farms in Jamaica and Pennsylvania," Int. J. Serv. Learning Eng., vol. 3, pp. 41-52, 2008.

[9] D. I. Massé, L. Masse, Y. Xia, and Y. Gilbert, "Potential of low-temperature anaerobic digestion to address current environmental concerns on swine production," J. Animal Sci., vol. 88, pp. E112-E120, October 2009.

[10] A. U. Ofoefule, E. O. Uzodinma, and C. N. Anyanwu, "Studies on the effect of anaerobic digestion on the microbial flora of animal wastes 2 : digestion and modelling of process parameters," Trends Appl. Sci. Res., vol. 5, pp. 39-47, 2010.

[11] A. Babaee and J. Shayegan. (July 2013). Anaerobic slurry co-digestion of poultry manure and straw: effect of organic loading and temperature. J. Environ Health Sci. Eng. [Online]. 11. p. 15. Available: http://www.ijehse.com/content/11/1/15

[12] M. L. Hutchison, L. D. Walters, S. M. Avery, F. Munro, and A. Moore "Analyses of livestock production, waste storage and pathogen levels and prevalences in farm manures," Appl. Environ. Microbiol, vol. 71, pp. 1231-1236, March 2005.

[13] K. A. Yongabi, P. L. Harris, D. M. Lewis, and M. O. Agho, "Preliminary study on the effect of anaerobically digested cow dung slurry on the antimicrobial activity of three medicinal plants," Afr. J. Micobiol. Res., vol. 3, pp. 168-174, April 2009.

[14] A. M. Ziganshin, T. Schmidt, F. Scholwin, O. N. II'inskaya, H. Harms, and S. Kleinsteuber, "Bacteria and Archaea involved in anaerobic digestion of distillers grains with solubles," Appl. Microbiol. Biotechnology, vol. 89, pp. 2039-2052, March 2011.

[15] A. E. Cioabla, L. Lonel, G-A. Dumitrel, and F. Popescu, "Comparative study of factors affecting anaerobic digestion of agricultural vegetal residues," Biotechnology Biofuels, vol. 5, p. 39, June 2012.

[16] Z. Z. Asam, T. G. Poulsen, A. S. Nizami, R. Rafique, G. Kiely, and J. D. Murphy, "How can we improve biomethane production per unit feedstock in biogas plants?" Appl. Energy, vol. 88, pp. 2013-2018, June 2011

[17] R. M. Poudel, D. R. Joshi, N. R. Dhakal, and A. B. Karki, “Anaerobic digestion of sewage sludge mixture for the reduction of indicator and pathogenic microorganisms," Sci. World., vol. 8, pp. 47-50, July 2010.

[18] A. Srijan, L. Bodhidatta, C. J. Mason, G. Bunyarakyothin, W. Jiarakul, and N. Vithayasai, "Field evaluation of a transport medium and enrichment broth for the isolation of Campylobacter species from human diarrheal stool samples," Open J. Med. Microbiol., vol. 3, pp 48-52, March 2013

[19] C. Côté, D. I. Massé, and S. Quessy, "Reduction of indicator and pathogenic microorganisms by psychrophilic anaerobic digestion in slurries," Bioresourc. Technol., vol. 97, pp. 686-691, March 2006.

[20] E. O. Uzodinma, A. U. Ofoefule, J. I. Eze, I. Mbaeyi, and N. D Onwuka, "Effect of some organic wastes on the biogas yield from carbonated soft drink sludge," Sci. Res. Essay., vol. 3, pp. 401-405 September 2008

[21] S. R. Carbone, F. M. da Silva, C. R. G. Tavares, and B. P. Dias Filho, "Bacterial population of a two-phase anaerobic digestion process treating effluent of cassava starch factory," Environ. Technol., vol. 23, pp. 591-597, November 2002,

[22] B. Molinuevo-Salces, M. C. García-González, C. González-Fernández, M. J. Cuetos, A. Morán, and X. Gòmez, "Anaerobic co-digestion of livestock wastes with vegetable processing wastes: A statistical analysis," Bioresour. Technol., vol. 101, pp. 9479-9485, December 2010.

[23] J. Li et al., "Assessment of the effects of dry anaerobic co-digestion of cow dung with waste water sludge on biogas yield and biodegradability," Int. J. Phys. Sci., vol. 6, pp. 3679-3688, 2011.

[24] Energy Commission of Nigeria, Rural Renewable Energy Needs and Five Supply Technologies, pp. 40-42, 1998.

[25] W. Choorit and P. Wisarnwan, "Effect of temperature on the anaerobic digestion of palm oil mill effluent," Electron. J. Biotechnology, vol. 10, pp. 376-385, July 2007.

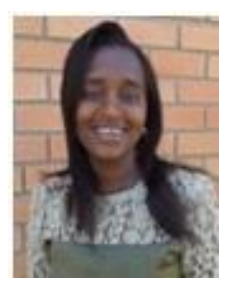

Christy Manyi-Loh was born at Buea, South West Region, Cameroon.

She owns a PhD degree in microbiology, obtained from the University of Fort Hare, Alice, South Africa. She equally possesses a bachelor of science and masters of science degrees in microbiology. During this period, she was awarded the senate prize for the best student in microbiology and the best student in research project given by the American Society of Microbiology, respectively.

Presently, she holds the position as a postdoctoral research fellow at the Institute of Technology, University of Fort Hare under the sponsorship of Claude Leon Foundation, South Africa through an award granted to her project.

She had published several papers in international peer-reviewed journals Dr. Manyi-Loh is a member of the South African Society of Microbiology and her current areas of research are renewable energy, specifically biomass energy (bio digesters). 


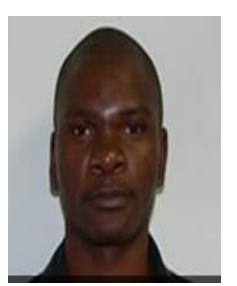

Sampson Mamphweli was born at Tshivhulana Village, Limpopo Province, South Africa.

$\mathrm{He}$ possesses a $\mathrm{PhD}$ degree in physics obtained from the University of Fort Hare, South Africa in 2010. He is also in possession of a master of environmental sciences degree from the University of Venda, Limpopo Province, South Africa obtained in 2004. He is a senior researcher at the University of Fort Hare, Institute of Technology, South Africa. He has previously worked for the University of Cape Town as a research technician and the South African National Parks as a research field assistant.

$\mathrm{He}$ has published a number of research articles in peer-reviewed journals and conference proceedings. His current areas of research interests include biomass gasification, solar energy technologies as well as energy efficiency. Dr. Mamphweli is a member of the South African Institute of Physics and he is also a recipient of the prestigious University of Fort Hare Vice Chancellor's emerging researcher medal for 2012.

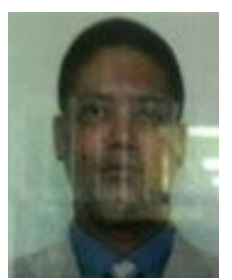

Edson Meyer was born in South Africa. He possesses a $\mathrm{PhD}$ degree in physics obtained from the Nelson Mandela Metropolitan University. $\mathrm{He}$ is also in possession of a bachelor degree with honour and a master degree in physics from the same university. $\mathrm{He}$ is the director of the Fort Hare Institute of Technology. $\mathrm{He}$ is also the Eskom chair of the M\&V Team in the Southern region, South Africa.

$\mathrm{He}$ is a member of the IEEE and a qualified certify professional of the South Africa measurement and verification association.

Prof. Meyer has published a number of research articles in peer-reviewed journals and conference proceedings. His current areas of research include solar energy technologies, energy efficiency, biomass as well as power engineering. He is also an energy consultant.

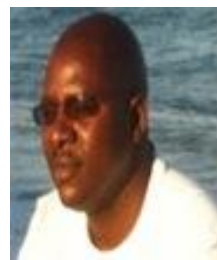

Michael Simon was born in Zimbabwe. He possesses a $\mathrm{PhD}$ degree in physics obtained from the University of Fort Hare, South Africa in 2010. He is also in possession of a bachelor degree with honour and a master degree in physics from same university. He is the University of Fort Hare engineer manager and head of the energy efficiency group at the Fort Hare Institute of Technology. He is also the team leader of the Eskom University of Fort Hare M\&V Team.

$\mathrm{He}$ is a member of the IEEE and a qualified professional of the South Africa measurement and verification association.

Dr. Simon has published a number of research articles in peer-reviewed journals and conference proceedings. His current areas of research include solar energy technologies, energy efficiency as well as power engineering. $\mathrm{He}$ is also an energy consultant.

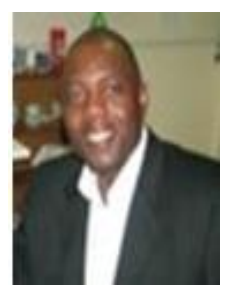

Anthony I. Okoh was born in Nigeria. He holds a Bsc (Hons), Msc and $\mathrm{PhD}$ degrees in microbiology at the Obafemi Awolowo University in Nigeria. He also holds 10 other diplomas and certificates in several aspects of biotechnology and molecular biology from reputable institutions on the continents of Africa, Asia, Europe and America. In the past, he was a senior lecturer at the Obafemi Awolowo University in Nigeria, and retired from the University to take up an appointment as associate professor of microbiology at the University of Fort Hare, South Africa in 2006. In January 2008, he was promoted to be a full professor of microbiology in the same university, and in January 2009, he was appointed to be the head of the Department of Biochemistry and Microbiology till now. He has therefore garnered extensive experience not only in teaching and research but also in administration, having also served in numerous committees in the University system including the appointment and promotion committee as well as elected for a two years term as president of Obafemi Awolowo University Staff Club in 2002.

His research expertise falls within the aegis of applied and environmental microbiology with particular emphasis on microbial water/ wastewater quality, and bioactive compounds of health and biotechnological importance. He has also been a recipient of such awards as Postgraduate Fellowship Award, Obafemi Awolowo University, Ile - Ife, Nigeria, 1990 1992; United Nations University Fellowship (1998); UNESCO Biotechnology Action Council Fellowship (2000), as well as several grants from the NRF, MRC, WRC, ESKOM, RS-DFID and ISRAR/APUA Currently his publication stood at over 300 publications made of over 190 journal articles; several conference presentations and nucleotide sequences deposited in the GenBank in my academic career of over two decades.

Prof. Okoh established his research group called Applied and Environmental Microbiology Research Group in the Department of Biochemistry and Microbiology of the University of Fort Hare. In 2008, he won the University of Fort Hare Vice-Chancellor Emerging Researcher Award, and in 2011, the Vice-Chancellor Senior Researcher Award. In 2009, he was invited to represent South Africa in the international collaboration on the Surveillance of Reservoirs of Antibiotic Resistance (ISRAR) under the auspices of the Alliance for the prudent use of Antibiotics (APUA) with headquarters in the Boston, USA. In 2011, he was elected as president of the South Africa Society for Microbiology (2011- 2013), and in November 2013, he was appointed as leader of the Water Resources for Sustainable Development Niche Area at the University of Fort Hare for the next five years. He is also a member of the South Africa National Committee on IUMS, and also a C2 (Established Researcher) rated researcher. 